\title{
EARLY DATA OF PATIENTS WITH PSEUDOMYXOMA PERITONEI FROM APPENDICEAL ORIGIN TREATED BY A STRATEGY OF CYTOREDUCTIVE SURGERY AND HYPERTHERMIC INTRAPERITONEAL CHEMOTHERAPY
}

\author{
Algirdas Šlepavičius, Vaidotas Turskis, Vitalija Nutautienė, Vitalijus Eismontas \\ Klaipeda University Hospital, Department of Abdominal and Endocrine Surgery, Lithuania
}

Key words: peritoneal neoplasma, appendiceal neoplasma, hyperthermic intraperitoneal chemotherapy, mitomycin.

\section{Summary}

Background. Appendiceal peritoneal pseudomyxoma (PMP) is very rare disease and its longterm prognosis is poor. The aim of this study was to evaluate the results of an aggressive treatment approach used in our institution for the last 4 years. Methods. We selected all patients with PMP from appendiceal origin who were treated by cytoreductive surgery (CRS) and hyperthermic intraperitoneal chemotherapy (HIPEC) at the Klaipeda University Hospital between January 2012 and January 2016. Data from all patients with PMP arising from the appendix were retrospectively collected and analyzed. Treatment consisted of complete surgical cytoreduction, followed by hyperthermic intraperitoneal chemotherapy with mitomycin at $42^{\circ} \mathrm{C}$ over 90 minutes. Ronnett's hystologic classification was used for tumor grading.

Results. A total of 6 patients underwent cytoreduction and peritonectomy plus HIPEC. Median age at diagnosis was 57 years (range, 39-67). All our patients were female. The previous surgery score at the moment of admission was PSS-2 for three patients, PSS-3 for 3 patients. Four patients were diagnosed as diffuse peritoneal adenomucinosis (DRAM) and two as peritoneal mucinous carcinomatosis( PMCA).

In all of the patients, optimal cytoreduction CC-0 (5 patients) and CC-1 (one patient) was achieved. The median peritoneal cancer index (PCI) was 17 (range, 14-25) as an indicator of disease extension. The median number of visceral resections performed per patient was 3 (range, 1-5). The median duration of CRS/HIPEC was 8 hours and 10 minutes (range, 7 hours and10 min. to 9 hours $20 \mathrm{~min}$ ). Mean postoperative stay was 13 days (range, $8-18$ ). The 30 days postoperative and in-hospital mortality were zero . One patient experienced temporary haemorhagic cystitis. The mean follow-up period was 28 months ( range, 8-45). At the time of analysis all patients are alive and without recurrence.

Conclusions PMP from appendiceal origin can be treated with curative intent in a large percentage of cases by cytoreductive surgery associated with HIPEC. This new approach could be performed safely with acceptable morbidity and mortality in selected patients treated in specialized centers.

\section{Introduction}

Pseudomyxoma peritonei (PMP) is a rare disease with the incidence of $1-2$ cases per million per year $[1,2]$. It is slowly progressive condition that usually arises from perforation of appendix due to an enlarging appendiceal adenoma or carcinoma, allowing mucin producing neoplastic cells to gain access to peritoneal cavity. PMP syndrome rarely metastases outside the abdominal cavity but remains a fatal illness as the space in the abdomen and pelvis required for normal function of the gastrointestinal tract becomes filled with copious amounts of the mucinous tumor [1,2]. Eventually patients develop terminal starvation because of abdominal distension and increased tumour volume [2].

Most cases of cystic ovarian mucinous tumors associated with pseudomyxoma peritonei are associated with metastases from an appendiceal tumor [3]. In women, cells become entrapped within the corpus hemorrhagicum and consequently, it is the detection of an ovarian cyst that often brings about the diagnosis of pseudmyxoma peritonei [3].

The pathologic classification of PMP is controversial 
and confusing. In 1995, Ronnett et al described three distinct cathegories of PMP on the basis of pathologic specimens ( $\mathrm{n}=109)$ : diffuse peritoneal adenomucinosis (DPAM), peritoneal mucinous carcinomatosis (PMCA), and an intermediate/discordant subtype (PMCA-I/D). DPAM originates from an appendiceal mucinous adenoma and produces abundant mucin but minimal mucinous epithelium that lacks significant cytologic atypia and mitoses. The prognosis of DPAM is good. An appendiceal adenocarcinoma causes PMCA, which features more mucinous epithelium and pathology that is typical of adenocarcinoma. The prognosis of PMCA is poor. The third category, PMCA-I/D, has characteristics of both DPAM and PMCA, and the prognosis is intermediate between the two. $[3,5]$.

The conventional treatment of PMP is surgical debulking repeated, as necessary to alleviate pressure effects. However, this treatment is palliative. Repeated debulking surgeries become more and more difficult due to progressively thickened intra-abdominal adhesions[6].

A combination of cytoreductive surgery(CRS) with hyperthermic intraoperative chemotherapy (HIPEC) was proposed by Sugarbaker. The rationale behind this strategy was to resect visible disease and any occult residual disease would be treated with a high concentration of chemotherapy and hyperthermia.[7 ].

CRS/HIPEC era evolved in Lituania in 2011[8].

The aim of our study was to evaluate early- term outcome data of patients with pseudomyxoma peritonei from appendiceal origin treated by a strategy of cytoreductive surgery and hyperthermic intraperitoneal chemotherapy in our University Hospital.

\section{Material and methods}

Patients with appendiceal tumors and peritoneal spread who underwent CRS/HIPEC from January 2012 to January 2016 were identified from a retrospectivelly collected database. No one patient did not receive any preoperative chemotherapy. Ronnett's histologic classification was used for tumor grading [3]. CT scan of the chest, abdomen, and pelvis and tumor markers (CEA, CA 19-9, and CA $125)$ were obtained prior to surgery. After review of the $C T$ scan and the patient's functional status $(\mathrm{ECOG}=0,1$, or 2$)$, CRS/HIPEC was recommended if complete cytoreduction was deemed feasible. Prior surgery score (PSS) was assessed as previously described by Jacquet et al [6]. Excllusion criteria include patients with extra-abdominal metastases, patients deemed medically unfit to undergo radical surgery based on preoperative medical assessment, and those patients whose disease was considered technically unresectable at the multidisciplinary team meeting.
Under general anesthesia, a xypho-pubic incision was made. Disease extent was assesed, at the beginning and after CRS, by calculating peritoneal carcinomatosis index (PCI) as previously described by Jacquet et al [7]. All resections were done as needed to achieve complete cytoreduction, including excision of previous scar and port sites, anterior abdominal wall peritonectomy, splenectomy, cholecystectomy, greater and lesser omentectomy, diaphragmatic and pelvic peritonectomies, stripping of peritoneum over omental bursa and porta hepaticus, and visceral peritonectomies. We classified all peritonectomy procedures to nine peritonectomy regions described by Sugarbaker $[7$ ]. Disease-free peritoneum was not removed. Bowel and solid organs were removed, if disease could not be cleared. Every attempt was made to avoid stomas and extensive small bowel resections to help preserve quality of life. In our study we used sentinel lymph node concept to help decide if right colectomy is necessary with an appendiceal tumors [7].

Complete cytoreduction (CC) was defined as no visible tumor nodules or nodules less than $2,5 \mathrm{~mm}$ in size, using the CC score adopted by the consensus panel recommendations on peritoneal surface malignancies [7]. Following CRS, HIPEC was performed using a closed technique for 90 min before performing any anastomoses. For HIPEC we used Performer HT by Rand company. Mitomycin-C was used with a dose of $25 \mathrm{mg} / \mathrm{m} 2 ; 10 \mathrm{mg}$ given at time zero and $15 \mathrm{mg}$ given $30 \mathrm{~min}$ later. The target outflow temperature was maintained at $41-42^{\circ} \mathrm{C}$, which requires an iflow temperature of $42,5^{\circ}$. We were keeping $40-41 \mathrm{C}$ in pelvis and $40-41 \mathrm{C}$ in subdiaphragmatic space. Flow rate $1200 \mathrm{ml} /$ min. . Urine output was maintained between 250 and 400 $\mathrm{cc} / \mathrm{h}$ during perfusion to avoid renal toxicity.

Patients were maintained in the intensive care unit during the first 24 hours of the postoperative period or until stable, and then transferred to the surgical floor. Early mobilization was encouraged, with physical therapy assistance on postoperatie day 1 . Low molecular weight heparin, compression stockings, and early mobilization were used for deep vein thrombosis prophylaxis. Patients were discharged when clinically stable; low molecular weight hepatin was continued on an outpatient basis for 21 days.

\section{Results and discussions}

From January 2012 to January 2016, 7 patients were treated for PMP from appendiceal origin in our institution; 6 of them were selected for our study following the criteria described above. One ,78 years old female patients was operated in our department. PCI was 36 and complete cytoreduction was not achieved. The major tumor debul- 
Table 1. Demographics, clinical and pathological characteristics of patients with pseudomyxoma peritonei (PMP)

ECOG score- the Eastern Cooperative Oncology group score. DRAM- disseminated peritoneal adenomucinosis, PMCA-peritoneal mucinous carcinomatosis, PCI-Peritoneal Cancer Index

\begin{tabular}{|l|c|c|c|c|c|c|}
\hline Characteristics & Nr.1 & Nr. 2 & Nr. 3 & Nr. 4 & Nr. 5 & Nr. 6 \\
\hline Age & 57 & 48 & 65 & 64 & 68 & 55 \\
\hline Sex & Female & Female & Female & Female & Female & Female \\
\hline ECOG score & 0 & 0 & 1 & 1 & 1 & 0 \\
\hline Pathological subtype & DRAM & DRAM & DRAM & PMCA & PMCA & DRAM \\
\hline $\begin{array}{l}\text { Interval between pri- } \\
\text { mary and secondary } \\
\text { surgeries (months) }\end{array}$ & 5 & 2 & 2 & 24 & 2 & 6 \\
\hline $\begin{array}{l}\text { Elevated CEA, } \\
\text { CA 19-9, CA 125 }\end{array}$ & - & + & + & + & + & + \\
\hline \multicolumn{1}{c}{ Co morbidities: } & & & & & & \\
\hline - Hypertension & + & - & + & + & + & - \\
\hline - Diabetus & - & + & - & - & - & - \\
\hline Prior surgical scor & 2 & 2 & 2 & 3 & 3 & 3 \\
\hline PCI & 16 & 18 & 14 & 14 & 12 & 25 \\
\hline
\end{tabular}

Table 2. Analysis of surgical treatment

\begin{tabular}{|l|l|l|l|l|l|l|}
\hline Surgery & Nr. 1 & Nr. 2 & Nr. 3 & Nr. 4 & Nr. 5 & Nr. 6 \\
\hline Omentectomy & + & + & + & + & + & + \\
\hline $\begin{array}{l}\text { Sentinel node biopsy } \\
\text { frosen section) }\end{array}$ & + & + & + & - & + & + \\
\hline $\begin{array}{l}\text { Number of peritonecto- } \\
\text { my procedures }\end{array}$ & 3 & 3 & 3 & 6 & 4 & 5 \\
\hline Small bowel resection & 0 & 0 & 0 & 1 & 1 & 2 \\
\hline Cholecystectomy & + & + & + & + & + & + \\
\hline Splenectomia & + & - & - & - & + & - \\
\hline Resection of large bowel & + & - & - & - & + & + \\
\hline Resection of diaphragm & - & + & - & - & - & - \\
\hline Appendectomy & - & - & - & - & - & - \\
\hline Hysterectomy & - & - & - & + & - & + \\
\hline
\end{tabular}

Table 3. Perioperative data

CC-completeness of cytoreduction. ICU-Intensive Care Unit

\begin{tabular}{|l|c|c|c|c|c|c|}
\hline Procedures & Nr. 1 & Nr. 2 & Nr. 3 & Nr. 4 & Nr. 5 & Nr. 6 \\
\hline $\begin{array}{l}\text { Duration of proce- } \\
\text { dure (H, min) }\end{array}$ & $8 \mathrm{~h}$. & $\begin{array}{c}7 \mathrm{~h} . \mathbf{3 0} \\
\text { min. }\end{array}$ & $\begin{array}{c}8 \mathrm{~h} . \text { 20 } \\
\text { min. }\end{array}$ & $\begin{array}{c}8 \mathrm{~h} .10 \\
\text { min. }\end{array}$ & $\begin{array}{c}8 \mathrm{~h} .50 \\
\text { min. }\end{array}$ & $\begin{array}{c}9 \mathrm{~h} . \mathbf{2 0} \\
\text { min }\end{array}$ \\
\hline Blood loss (ml) & 1500 & 800 & 760 & 700 & 850 & 600 \\
\hline $\begin{array}{l}\text { Blood transfusion } \\
\text { (ml) }\end{array}$ & 1200 & 900 & 950 & 800 & 900 & 600 \\
\hline $\begin{array}{l}\text { Blood product } \\
\text { transfusion/first } \\
\text { 24h(ml) }\end{array}$ & 2000 & 1550 & 1100 & 1200 & 1300 & 900 \\
\hline CC & 0 & 0 & 0 & 1 & 0 & 0 \\
\hline ICU stay (days) & 3 & 3 & 4 & 4 & 3 & 3 \\
\hline Complications & - & $\begin{array}{c}\text { Hae- } \\
\text { mor- } \\
\text { hagic } \\
\text { cystitis }\end{array}$ & - & - & - & - \\
\hline Postoperative stay & 12 & 15 & 10 & 11 & 10 & 18 \\
\hline $\begin{array}{l}\text { Follow-up } \\
\text { time(months) }\end{array}$ & 45 & 38 & 32 & 25 & 16 & 8 \\
\hline
\end{tabular}

king was undertaken. She was not included in our study. Appendiceal origin was determined by histopathologic and immunoanalysis in all of our patients. Median age at diagnosis was 57 years (range, 39-67). All our patients were female. Five of them were operated by gynaecologists for Krukenberg tumor as primary surgery and one patient for acute perforated appendicitis. The previous surgery score (PSS) at the moment of admission was PSS-2 for three patients, PSS-3 for 3 patients. In five patients even one tumor marker was elevated. Four patients were diagnosed as DRAM and two as PMCA. Patient demographic, clinical and pathological data are summarized in table 1.

A total of 6 patients underwent cytoreduction and peritonectomy plus HIPEC. In all of the patients, optimal cytoreduction CC-0 (5 patients) and CC-1 (one patient) was achieved. The median PCI score was 17 (range, 14-25) as an indicator of disease extension. The median number of visceral resections performed per patient was 3 (range, 1-5). (Table 2).

The median duration of CRS/HIPEC was 8 hours and 10 minutes (range, 7 hours and 10 min. to 9 hours $20 \mathrm{~min}$ ). Four patients received intraabdominal hypertermic chemotherapy, one patient - thoracoabdominal (after resection of diaphragm) and one patient (retroperitoneal PMP) retroperitoneal-peritoneal chemotherapy. Mean postoperative stay was 13 days (range, 8-18). One patient experienced temporary haemorhagic cystitis. The 30 days postoperative and in-hospital mortality were zero. Median follow-up time was 28 months (range, 8-45). (Table 3).

At the time of analysis all patients are alive and without recurrence.

\section{Discussion}

Traditionally, debulking surgery was the standard treatment of PMP. Followed by multiple operations for successive recurrences. The short -term results of debulking surgery are excellent, but the disease is almost certain to recur after a short interval, requiring numerous operations, until the disease finally becomes inoperable[6 ]. CRS and HIPEC intraduced by Sugarbaker [7] has led to a marked improvement in survival rate compared with historical data, reaching differences in 5-years survival rates from $40 \%$ to $74 \%[6]$.

Chua et al. evaluated outcome and long-term 
survival after CRS and HIPEC consolidated through an international registry study. This was a retrospective multi-institutional registry established through collaborative efforts or participating units affiliated with the Peritoneal Surface Oncology Group International. Two thousand two hundred ninety-eight patients from 16 specialized units underwent CRS for PMP. Treatment-realated mortality was $2 \%$ and major operative complications occurred in $24 \%$ of patients. The median survival rate was 98 months $(16,3$ years) and the median progression-free survival rate was 98 months ( 8,2 years), with 10 - and 15 -year survival rates og $63 \%$ and $59 \%$, respectively. Multivariate analysis identified prior chemotherapy treatment $(\mathrm{P}<.001)$, peritoneal mucinous carcinomatosis (PMCA) histopathologic subtype $(\mathrm{P}<.001)$, major postoperative complications $(\mathrm{P}=.008)$, high peritoneal cancer index $(\mathrm{P}=.013)$, debulking surgery (completeness of cytoreductions (CCR), 2 or 3; $\mathrm{P}<.001$ ), and not using HIPEC $(\mathrm{P}=.030)$ as independent predictors for a poorer progression-free survival. Older age $(\mathrm{P}=.006)$, major postoperative complications $(\mathrm{P}<.001)$, debulking surgery (CCR 2 or $3 ; \mathrm{P}<.001$ ), prior chemotherapy treatment $(\mathrm{P}=.001)$, and PMCA histopathologic subtype ( $\mathrm{P}$ $<.001)$ were independent predictors of a poorer overall survival. Reviewers concluded the combined modality strategy for PMP may be performed safely with acceptable morbidity and mortality in a specialized unit setting with $63 \%$ of patients surviving beyond 10 years. Minimizing nondefinitive operative and systemic chemotherapy treatments before definitive cytoreduction may facilitate the feasibility and improve the outcome of this therapy to achieve long-term survival. Optimal cytoreduction achieves the best outcomes[10].

The aim of our study is to present our first experience of modern treatment of PMP of appendiceal origin in Klaipeda University Hospital.

Selecting patients for CRS/HIPEC remains challenging. Reviewing previous reports to establish guidelines for the selection is difficult partly because of the lack of consensus about pathology[4]. Ronnett's classification is the most widely used, but different classification systems have been suggested [9]. In addition, extent of disease is not reported in all studies. At our institution, we do not consider grade or extent of disease a contraindication to CRS/HIPEC. We make every effort to achieve CC, while minimizing visceral resection and preserving quality of life after surgery. These decisions are usually made intraoperatively. However, efforts for standardization of pathological reports are essential for future research and advancement in the treatment of this disease.

This study is a retrospective analysis with inherent li- mitations and relatively short mean follow-up and small number of patients. We did not deselect patients based solely on pathology type and tumor burden, and we closely monitor our patients postoperatively. To the best our our knowledge it the first report about surgical treatment of PMP in Lithuania.

\section{Conclusions}

PMP from appendiceal origin can be treated with curative intent in a large percentage of cases by cytoreductive surgery associated with HIPEC. This new approach could be performed safely with acceptable morbidity and mortality in selected patients treated in specialized centers.

\section{References}

1. Brueggen C, Baird G, Meisheid A. Pseudomyxoma peritonei syndrome of appendiceal origin: an overview. Clin J Oncol Nurs 2007; 11(4): 1092-1095.

2. Brendan MJ, Cecil TD. The etiology, clinical presentation and management of pseudomyxoma peritonei. Surg Clin N Am 2003; 12: 585-603.

3. Ronnett BM, Zahn CM, Kurman RJ, Kass ME, Sugarbaker PH, Shmookler BM. Disseminated peritoneal adenomucinosis and peritoneal carcinomatosis: A clinicopathological analysis of 109 cases with emphasis on distinguishing pathologic features, site of origin, prognosis and realtionship to Pseudomyxoma peritonei. Am J Surg Pathol 1995; 19: 1390-1408.

4. Nakakura EK. Pseudomyxoma peritonei: more questions than answers. Journal of Clinical Oncology 2012; 20: 2429-2430.

5. Ronnett BM, Yan H, Kurman RJ, Shmookler BM, Wu L, Sugarbaker PH. Patients with pseudomyxoma peritonei associated with disseminated peritoneal adenomucinosis have a significantly more favorable prognosis than patients with peritoneal mucinous carcinomatosis. Cancer 2001; 92: 85-91.

6. Miner T, Shia J, Jaques D, Coiti D. Long term survival following treatment of Pseudomyxoma peritonei: an analysis of surgical therapy. Ann Surg 2005:241:300-308.

7. Jacquet $\mathrm{P}$, Sugarbaker OH. Clinical research methodologies in diagnosis and staging of patients with peritoneal carcinomatosis. Cancer Treat Res 1996; 82: 359-374.

8. Eismontas V, Turskis V, Cesas A, Slepavicius A. Experience of HIPEC and cytoreductive surgery in Klaipeda University Hospital.Sveikatos mokslai/Health Sciences 2013;23:73-78.

9. Bradley RF, Stewart JH, Russell GB, Levine EA, Geisinger KR. Pseudomyxoma peritonei of appendiceal origin: a clinicopathologic analysis of 101 patients uniformly treated at a single institution, with literature review. Am J Surg Pathol 2006; 30: 551-559.

10. Chua TC, Moran BJ, Sugarbaker PH, et al. Early- and long term outcome data of patients with pseudomyxoma peritonei from appendiceal origin treated by a strategy of cytoreductive surgery and hyperthermic intraperitoneal chemotherapy. J Clin Oncol 2012;30:2449-56. 


\section{APENDIKULIARINĖS KILMĖS PILVAPLE்VE்S PSEUDOMIKSOMOS GYDYMAS CITOREDUKCINĖMIS OPERACIJOMIS IR INTRAOPERACINE HIPERTERMINE CHEMOTERAPIJA. PIRMOJI PATIRTIS}

A. Šlepavičius, V. Turskis, V. Nutautienė, V. Eismontas

Raktažodžiai: kirmèlinè atauga, pilvaplèvès pseudomiksoma, citoredukcija ir HIPEC, mitomicinas.

Santrauka

Tikslas. Pilvaplèvès pseudomiksoma (PPM) dèl kirmèlinès ataugos naviku yra labai reta, o ilgalaikè prognozė bloga.Tikslas - apibendrinti pirmają citoredukcinių operacijų (CRS) ir hiperterminès intraperitoninès chemoterapijos (HIPEC) patirti pacientams, sergantiems pilvaplèvės pseudomiksoma dèl kirmélinès ataugos auglių.

Pacientai ir metodai. Atlikta retrospektyvi analizė 6 pacientų, kuriems KUL 2012/01- 2016/01metais buvo atlikta citoredukcinè operacija ir HIPEC dèl apendikuliarinès kilmès pilvaplèvès pseudomiksomos.

Atlikta priešoperacinių (amžius,lytis, pilvaplèvės karcinomatozès indeksas (PKI), patohistologinis PPM tipasir kt.), intraoperacinių (operacijos trukmé, radikalumas, sarginio limfmazgio būklè, netekto kraujo kiekis ir kt.) ir operacijų apimties analizè. Hiperterminei intraoperacinei terapijai naudota uždara metodika. İtekejjimo temperaratūra 42,5 lapsniai C. Visiems ligoniams naudo- tas Mitomicinas C 25mg/m². .Pilvaplèvès perfuzijos trukmè $90 \mathrm{~min}$.

Rezultatai. Vidutinis operuotų ligonių amžius buvo 57 metai (svyravo, 39-57). Visos pacientès buvo moterys. Keturioms pacientèms nustatyta difuzinè peritoninè adenomucinozè, 2 pacientèms peritoninè mucininė karcinomatozè. Pilvaplèvès karcinomatozès indekso vidurkis buvo 17 (svyravo,14-25). Radikali citoredukcija (CC-0/CC-1) buvo atlikta visiems ligoniams. Vidutinė CRS/HIPEC trukmé buvo 8 val. ir 10 min. (svyravo, 7 val. ir 10 min.- 9 val. 10 min.) Vidutinis vienam pacientui atliktų pilvo organų rezekcijų skaičius vienos operacijos metu buvo -3 (svyravo,1-5). Pooperacinių mirčių nebuvo. Vienai ligonei po operacijos išsivyste hemoraginis cistitas. Pooperacinio stebėjimo vidutinè trukmè 28 mèn. (svyravo nuo 8 iki 45 mẻn). Visi mūsų operuoti pacientai šiuo metu sveiki ir be ligos atkryčio požymių.

Apibendinimas. Citoredukcinès operacijos ir HIPEC gydant pilvaplèvès apendikuliarinès kilmès pseudomiksomą yra pakankamai saugus būdas. Artimieji gydymo rezultatai yra geri. Ypač svarbu geriems gydymo rezultatams pasiekti yra tinkama pacientu atranka ir radikali citoredukcija.

Adresas susirašinèti: algisle@gmail.com

Gauta 2016-10-13 